UDC 681.5.013

DOI https://doi.org/10.32838/2663-5941/2019.5-1/27

Stepanets O.V.

National Technical University of Ukraine "Igor Sikorsky Kyiv Polytechnic Institute"

Shram D.O.

National Technical University of Ukraine "Igor Sikorsky Kyiv Polytechnic Institute"

\title{
APPLICATION OF FAULT-TOLERANT AUTOMATIC CONTROL SYSTEMS ON THERMAL POWER PLANTS
}

The purpose of the article is to compare the production of electricity at different types of power plants, in particular, to get acquainted with the sphere of modern thermal power engineering of Ukraine, to form a general overview of the problems of automatic control systems of thermal and energy objects and complexes. The energy market requires a clear adherence to the indicators of the quality of electricity, which is influenced by the status of the main production assets of the power plants and the quality of their management. In modern world paradigm of automatic control theory development, fault-tolerant control systems aimed at ensuring trouble-free technological processes are promising.

The paper describes the dynamics of changes in the ratio between different energy sources in recent years, which will affect the direction of research by evaluating the use of energy sources in the future. There is low level of tolerance towards performance degradation in power generation plants (PGPS). They have much of issues and potential faults, like low productivity, losses of production, human safety, environmental hazards and pollution. To avoid undesirable conditions and to supply uninterrupted power to industrial and other users, power generation industry has started to use Fault Detection and Isolation (FDI) methods in power generation plants. The current state of thermal power plants used in shunting modes is considered. The scheme of operation of a thermal power plant is considered in detail, the key elements that require control and application of fault-tolerant control systems are identified. The main aspects of failures in automatic control circuits are given. The typical power plant is analyzed for these aspects and the examples show causes and locations of failures in the main structural elements of the power plant: turbines, boilers, including combustion subsystems, water supply, steam generation and steam use. There is shown the role of fault-tolerant systems in the management strategy of the facility, which is implemented both at the design and in operation stages, in the article.

Key words: power energy generation, fault detection and isolation, fault diagnosis, fault-tolerant system, thermal power plant, maintenance strategy.

Problem definition. Ukrainian power sector is the most significant component of the social overhead capital and of industrial potential. Ukrainian economic is affected directly by the utilities sector trough growth of GDP. During last 2 years industrial growth has been increasing after its fall before in 2015 , so power requirements are also increasing rapidly. Electricity consumption (net) by industries of the national economy and the population during the 10 months of 2018 amounted to 99484.6 million $\mathrm{kWh}$, that is 2351.0 million $\mathrm{kWh}$ (or $2.4 \%$ ) more than during the same period in 2017 [1, p. 3]. As a result, there is low level of tolerance towards performance degradation in power generation plants (PGPs). Power units of pulverized coal-fired plants, which remained without the Donbass anthracite, reduced the load, and in some cases even stopped, therefore the country was forced to buy coal in South Africa, Australia and Russia [2, p. 20].

There are much of issues and potential faults in power generation plants, like low productivity, losses of production, human safety, environmental hazards and pollution. A study by Rosen [3, p. 155] has revealed, that saving of about $30 \%$ in maintenance cost can be achieved by simply changing from preventive maintenance to Condition Based Maintenance (CBM) in which a Fault Detection and Isolation (FDI) system plays a major role. Advancement into FDI algorithm, therefore, would mean significant improvement in the CBM capacity. So research in the area of root technological clauses of power plants failures and preventive fault detection methods are very important.

Overview of Thermal Power Plants and their problematic. The main load in the 2014-2015 biennium was at nuclear power plants, that's why all preventive and repair measures were delayed. Due to the temporary occupation of Crimea, the prospects for further growth of own natural gas production have gone nastier, and because of hostilities, the outflow of Western investors funds from the energy market of Ukraine took place. 
In January-October 2018, the volume of electricity produced by power plants, included in the UES of Ukraine, amounted to 15870.5 million $\mathrm{kW}^{*} \mathrm{y}$ (Fig. 1), which is 1069.0 million $\mathrm{kW}^{*} \mathrm{y}$ or $1.2 \%$ more than the corresponding period of 2017 [1, p. 9]. At the same time, thermal power plants (TPPs) and central heating and power plants (CHPPs) produced electricity at 1280.7 million $\mathrm{kW}^{*} \mathrm{y}$, or $23 \%$ more than the corresponding period of 2017 and amounted to 6 835.2 million $\mathrm{kW}^{*} \mathrm{y}$. A very important aspect regarding the heat and power complex is the formation of local energy systems based on the economically efficient consideration of the potential of local fuels and logistics. It is also a contribution to the reconstruction of district heating units in order to minimize losses and support the implementation of cogeneration projects at CHPPs and cogeneration of biofuels [4, p. 14]. The reconstruction of CHPPs should be carried out in accordance with the requirements of environmental standards and the introduction of a system of commercial calculations based on quality indicators for the provision of heating and cooling services. Equally important is reassessment of technical and economic indicators of projects for long-distance transport of heat from large energy facilities (TPPs and NPPs) and the decision on the feasibility of their implementation. Programs must be formed to support the modernization or replacement of old boilers, the transfer of heat consumers to autonomous and / or individual heating, where this is economically feasible. In current conditions of limited types and high cost of coal extracted in Ukraine for heat power engineering, the task is to transfer a few coal-fired TPPs to the coal of a gas group in accordance with technical and economic feasibility.

The first Energy Strategy of Ukraine for the period up to 2030 was approved in 2006, but changes in the country's economy have necessitated its revision already in 2012. However, the proposed version of the Energy Strategy again did not consider the real energy balance and investment climate in the country then, as well as the fact, that in 2005-2012 the GDP growth in Ukraine was accompanied by a high energy intensity of the gross product. New Energy strategy 2035 [5, p. 2] has been implemented by the Cabinet of Ministers of Ukraine. At the same time, in addition to satisfying demand in the short and medium term, the strategic task of the next ten years is to prepare Ukraine's energy system for large-scale upgrading of capacity after 2025 .

The detailed chain of technological processes from the delivery of fuel to TPPs to producing of electricity is displayed on the technological scheme [6, p. 173] on Fig. 2. We will discuss possible faults and failures in TPPs after the overview of the process. At TPPs that burn gas-oil fuel, the fuel-handling facility is

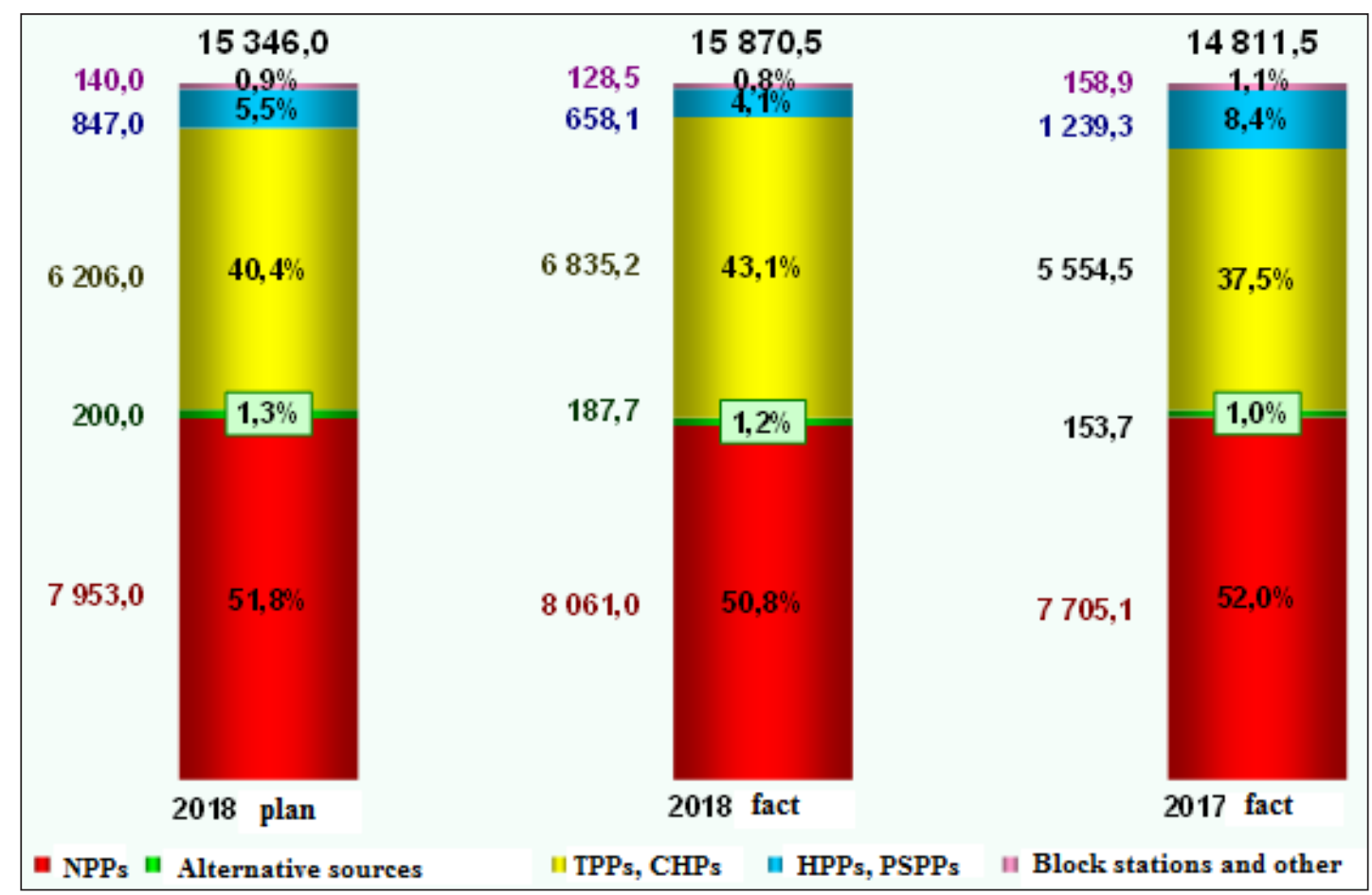

Fig. 1. Structure and volumes of electricity production by the United Energy System (UES) of Ukraine in 2017-2018, mln. kW*y (Source - The Ministry of Energy and Coal Industry of Ukraine (MECIU) as on the 27th of July 2019) 
significantly simplified compared to pulverized TPPs; a coal warehouse, a crushing department, a system of conveyors, a raw coal and dust bunker, and a system for ash collecting and ash removal are not available.

The heated steam from the output header of the steam superheater enters the high-pressure cylinder (HPC) of the steam turbine 26a via the steam line 25. After the HPC, steam over the "cold" intermediate superheat steam line 27 returns to the boiler and enters the intermediate superheater 28 , in which it overheats again to the temperature of the fresh steam or close to it. The "hot" intermediate-heating line 27 a supplies steam to the medium-pressure cylinder (MPC) $26 \mathrm{~b}$, then into the low-pressure cylinder (LPC) 26b and from it - to the turbine condenser 29. From the condensate collector condenser condensate pumps of the first stage 30 supply condensate to the filters of the condensate purification installation 31 , after which the condensate is pumped through the second stage condensate pump through a group of low-pressure heaters (LPH) 33 to deaerator 34. In a deaerator, water is brought to a boil and at the same time released from aggressive $\mathrm{O} 3$ and $\mathrm{CO} 2$ gases dissolved in it, which prevents corrosion in the steam-water path. The deaerated feedwater from the storage tank of the deaerator supplied by pump 35 is fed through a group of high-pressure heaters (HPH) 36 to economizer 37. This closes the steam and water path, which includes the steam and water paths of the boiler and turbine plant.

The steam and water path of the TPP is the most difficult and responsible, because in this path there are highest metal temperatures and highest vapor and water pressures. To ensure the functioning of the steam and water path, a system for preparing and supplying additional water is also needed to compensate the loss of working fluid and technical water supply system of the TPP to supply cooling water to the turbine condenser.

The cooling water is pumped through the condenser tubes by the circulating pump 40 and then enters the tower cooler (cooling tower) 41, where, due to evaporation, the water is cooled to the same temperature difference to which it is heated in the condenser. The water supply system with cooling towers is used mainly in CHPP. The TPP uses water supply systems with cooling ponds. When evaporative cooling of water, the evaporation is approximately equal to the amount of steam condensed in the condensers of the turbines. Therefore, it is necessary to feed water supply systems, usually water from a river.

An electric generator 42 , rotated by a steam turbine, generates an alternating electric current, which through a step-up transformer 43 goes to busbars 44 of the open distribution system (ODS) of the TPP. To the generator terminals through auxiliary transformer 45 is also attached own flow busbars 46 . Thus, own needs of the power unit (electric motors of auxiliary units - pumps, fans, mills, etc.) are powered by the power unit generator. In special cases (emergency situations, load shedding, starts and stops), auxiliary power supply is provided via a backup transformer from the switchgear busbars.

Thus, the described technological scheme of TPPs is a complex of interconnected paths and systems: the fuel path, dust preparation system, steam-water path,

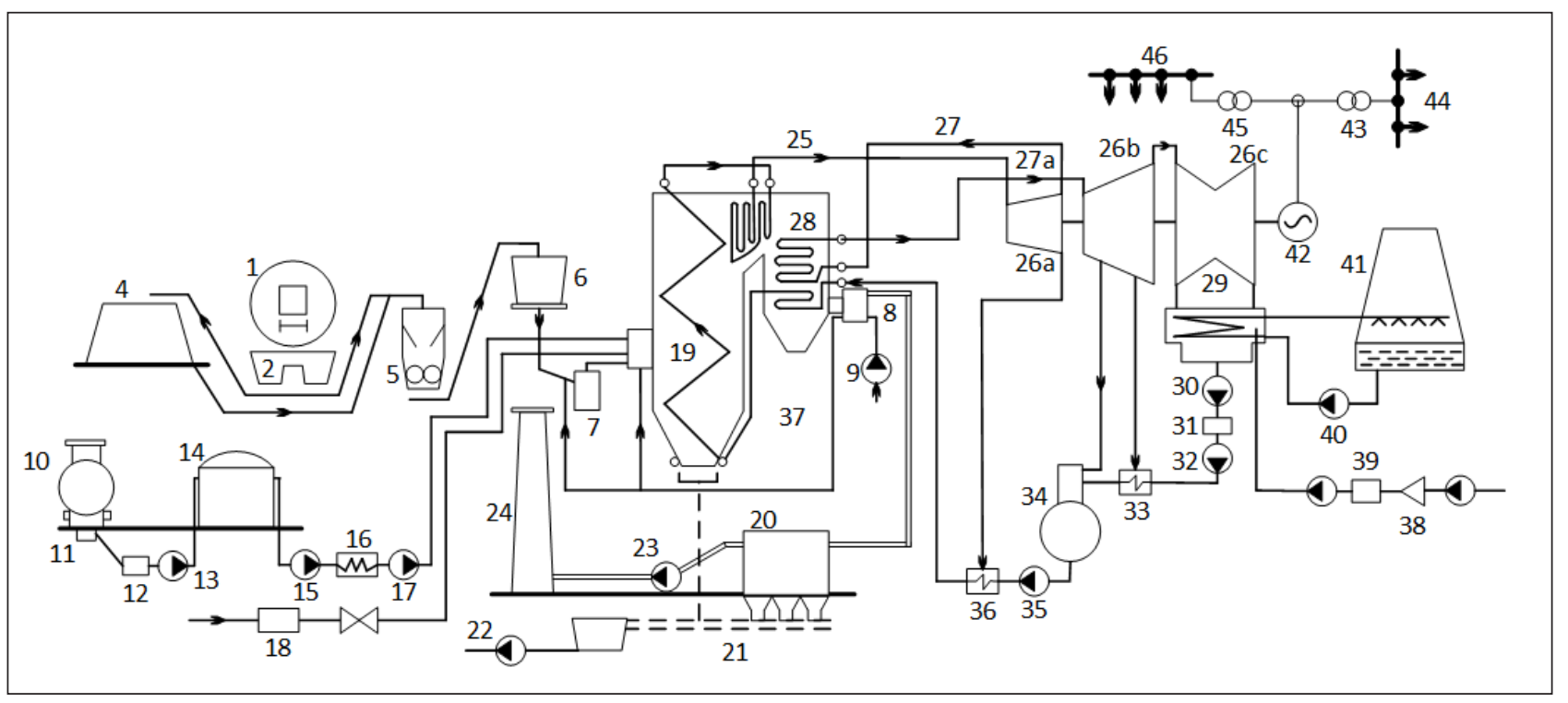

Fig. 2. Process flow-chart of a TPP 
gas-air path, slag removal system, electrical part, system of additional water preparation, technical water supply system.

Heat recovery steam generator (HRSG) is a part of the TPP. The HRSG has a steam drum, water drum, water-walls, economizer (37), pre-heaters $(33,36)$, and feed-water pumps (35) as sub units. The prominent performance related faults common in the units include malfunction in the feed-water pump (i.e. damaged seals and erosion of impellers), tube leaks (system fault), and disturbance in the remaining critical components. Failure in the HRSG causes the exhaust gas exit temperature to increase, and exhaust gas pressure and steam production to decrease.

Setting objectives. To avoid undesirable conditions and to supply uninterrupted power to industrial and other users, power generation industry has started to use Fault Detection and Isolation (FDI) methods in conventional and renewable energy power generation plants to improve reliability and availability of power plants. Some actions are needed to be done for this purpose:

1) to structure and to localize failures in TPPs;

2) to find place of FDI methods in maintenance strategies.

Applications of FDI methods in TPPs. Thermal power plants deliver electricity that could be produced either from natural gas or coal. Several closed loop controls are used to convert chemical energy into electrical energy in any TPPs. All the closed loops should be closely monitored and precisely controlled to improve the overall efficiency of the power plant. In every closed loop system of the plant there are three types of fault [7, p. 39]: system, actuator and sensor. The first is system fault, in which the mechanical structure of the system or component is prone to damage (i.e. leak fault in pipe lines or in the tank). The second one is actuator fault, in which the characteristic of the actuator changes due to mechanical wear and tear (i.e. in pneumatic actuator faults incorrect pressure supply, diaphragm leakage, plug aging etc.). This may drastically change the system behavior, resulting in degradation or even instability. The third fault is sensor fault, in which measured value may be higher or lower than the actual one (i.e. sensor accuracy, missed calibration etc.). By applying FDI methods into closed loop system incorporating effective maintenance schedule, gives optimum efficiency of the overall plant. Improving efficiency and reliability of TPPs depend on the steam turbine control systems. For example, major failures in a steam turbine TPPs $<220 \mathrm{MW}$ [3, p. 25] in different capacity modes are represented on Fig. 3.

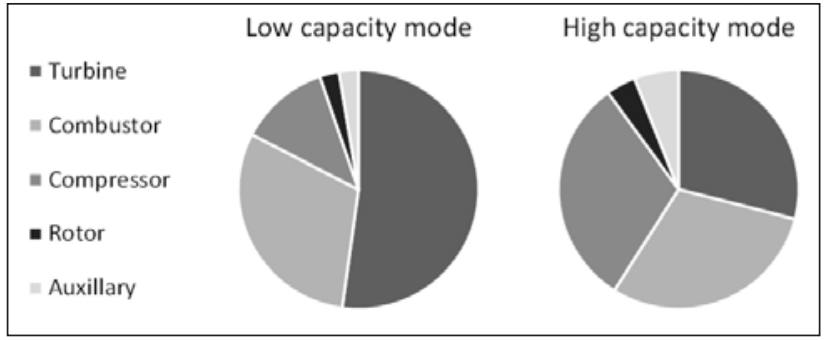

Fig. 3. Major failure in a steam turbine TPPs $<220$ MW

Let's summarize possible faults in TPPs in Table 1. The steam turbine (26a) fault is a major fault in TPPs from the perspective of economic losses due to failure or lack of maintenance of the steam turbine. Maintenance expenses in the TPPs are closely connected to a steam turbine. So, detecting an early fault in turbine and diagnosis is mandatory for reliability of the power plant. Several researchers have focused on various FDI methods that are applied to the turbine for TPPs [7, p. 42]. Other key faults are failures of sensors in TPPs. The sensor is an essential part of any closed loop system for measured variable, and a malfunction in sensor results in deviate the controlled variable significantly, and hence affects the plant efficiency. The various FDI methods are applied to prevent sensor faults [8]. The third important fault is actuator fault. Failure to control variable would degrade the quality and further to dangerous situations. If the actuator fails or of a fault occurs, in boiler furnace (19) exhaustion level control, the superheated steam quantity reduces drastically and affects the efficiency of the turbine. Low levels of water in economizer (37) damage due to overheating by the superheated steam. If combustion control fail affects the combustion efficiency. Various FDI methods are discussed to overcome the effect of the actuator fault in any system.

There are three types [9, p. 258] of maintenance strategy (Fig. 4). The first one is Design-Out Maintenance (DOM), that deals with maintenance considerations at the manufacturing stage of the equipment itself. The intention of this strategy is to do away with any maintenance requirement, due to the limitation of the material properties and manufacturing method, and design the parts and equipment for finite life. It is however, difficult to implement this strategy practically. The second one is called Corrective or Reactive Maintenance (CM). In this kind of approach parts are replaced when they fail. It is adoptable when the frequency of the failure of parts is high. It however causes unnecessary down-time leading to production losses. The third 
Potential faults in continuous operating process of TPP

\begin{tabular}{|l|l|l|}
\hline \multicolumn{1}{|c|}{$\begin{array}{c}\text { Potential faults in } \\
\text { TPPs }\end{array}$} & \multicolumn{1}{|c|}{ Description } & \multicolumn{1}{c|}{ Comments } \\
\hline $\begin{array}{l}\text { Steam turbine health } \\
\text { monitoring and } \\
\text { control design. }\end{array}$ & $\begin{array}{l}\text { Indeed, turbine health monitoring and control } \\
\text { is an essential part of thermal power plants } \\
\text { to improve efficiency. However, fault occurs } \\
\text { (i.e. sensor, actuator and system faults) during } \\
\text { the operation of the turbine. Increasing steam } \\
\text { turbine efficiency output, various fault tolerant } \\
\text { control (FTC) strategies have been applied. }\end{array}$ & $\begin{array}{l}\text { The steam turbine of a TPP may cause major } \\
\text { losses in terms of efficiency and maintenance. } \\
\text { It is major equipment in any TPPs. } \\
\text { in the efficiency of TPPs. }\end{array}$ \\
\hline $\begin{array}{l}\text { Combustion control } \\
\text { mechanism and flue } \\
\text { gas heat recovery. }\end{array}$ & $\begin{array}{l}\text { Combustion controls adjust coal and air flow } \\
\text { to optimize steam production for the steam } \\
\text { turbine/ generator set. In TPPs, steam reheater } \\
\text { or super heater pipe leakage may reduce } \\
\text { combustion efficiency, steam temperature, } \\
\text { furnace slagging and fouling and NOX } \\
\text { formation. }\end{array}$ & $\begin{array}{l}\text { For proper combustion control in boiler, } \\
\text { continuously provide enough air and fuel. } \\
\text { System fault occurs in steam heater, super } \\
\text { heater and reheater and fuel pipe line, } \\
\text { dropping the combustion efficiency. Heat } \\
\text { recovery is important for utilizing maximum } \\
\text { energy from the flue gases. Leaks faults leads } \\
\text { to in heat recovery cycle occurs energy losses. }\end{array}$ \\
\hline $\begin{array}{l}\text { Boiler feedwater } \\
\text { control. }\end{array}$ & $\begin{array}{l}\text { The drum water level control is essential in } \\
\text { boiler control. Due to increasing and reducing } \\
\text { demand of the steam drum water level must be } \\
\text { controlled precisely. Actuator's faults lead to } \\
\text { hazardous situations, which are caused byo an } \\
\text { insufficient amount of water in the boiler drum. }\end{array}$ & $\begin{array}{l}\text { Actuator fault occurs in the power plant } \\
\text { system reduce efficiency of turbine due to } \\
\text { an insufficient amount of superheated steam } \\
\text { produced by the boiler. }\end{array}$ \\
\hline
\end{tabular}

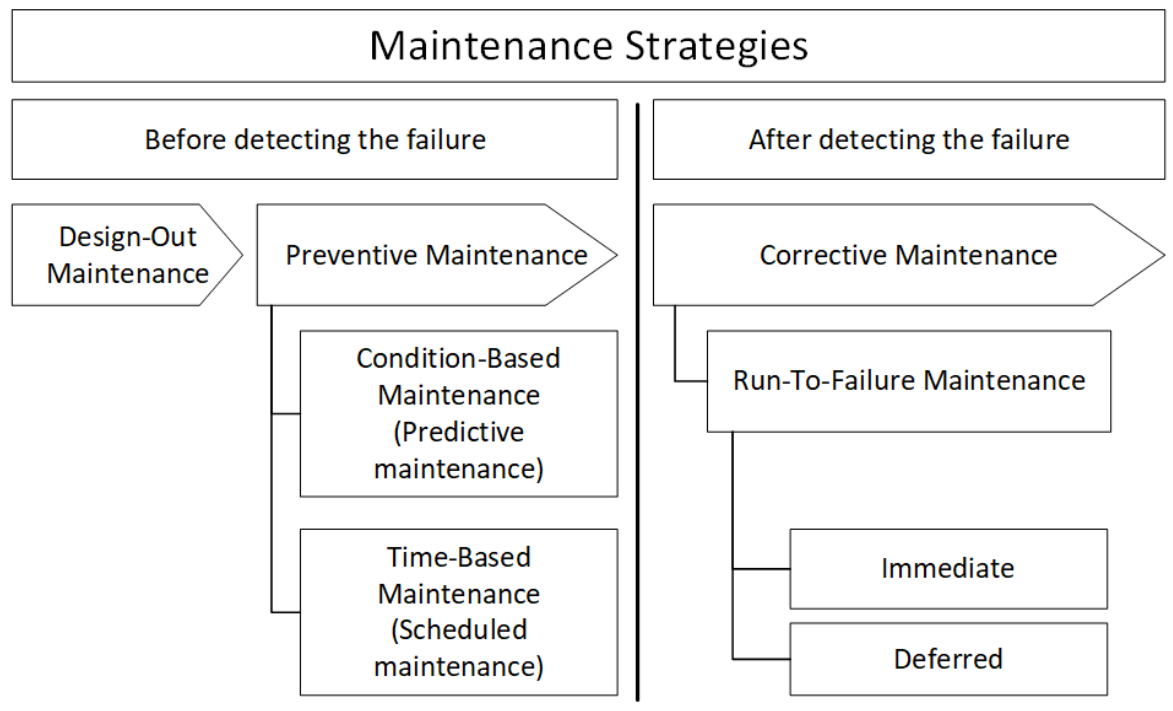

Fig. 4. Types of Maintenance Strategies

type is known as Preventive Maintenance (PM). Further PM is divided into Time-Based Maintenance (TBM) and Condition Based Maintenance (CBM). TBM schedule is predefined and applied to the plant or equipment to prevent failure before it occurs. Unlike TBM, CBM is a proactive strategy in the sense that it is recommended based on existing conditions of the plant. The advantage of the CBM strategy is reducing unnecessary shutdown and maintenance costs.

CBM strategy is employed in TPPs to improve efficiency and to reduce production costs. CBM involves three steps: data acquisition, data processing, and decision making [3, p. 47]. FDI-based scheme is used for successful application and execution of the CBM scheme.

One of the key tasks of modernization of the power industry is the construction of such automation systems that will meet the latest requirements for reliability and safety of operation of facilities. From the control theory perspective, the key problem is building of fault-tolerant systems of automatic control of heat and power complexes. Vibration monitoring and loose 
part monitoring, noise analysis have been extensively applied with success in various PGPs. It is recognized, that on-line monitoring of instruments and equipment in power plant industry brings benefits to plant availability and results in better economy. Some commercial products have been developed and are increasingly used in power plants. Encouraging results have been obtained for reactor core monitoring in NPPs, furnace temperature monitoring in TPPs and transient identification. It is very important to provide predictive analytics on modern power plants, because the speed of equipment failure response can have catastrophic consequences for the population and the environment.

Careful attitude towards the environment is inherent in modern leading companies. For example [10], it is expected that the technological re-equipment of the pyloric system of the power generation unit 7 at Prydniprovska TPP (DTEK) for the conversion of burning of the domestic coal type "G" and, in particular, the modernization of the dust preparation system, which includes Modicon M580 controllers with HSBY technology, will reduce emissions of harmful substances such as sulfur dioxide and nitrogen oxide. The solution was executed by the system integrator, the company "Ipra-Soft", with the use of technology and equipment of Schneider Electric. It can be a benchmark of the studied FDI approach.
Conclusions. In the country's energy strategy, noting the growing interest in alternative energy sources and the prevalence of nuclear power, thermal power plants will continue to play a significant role. They are the main source of energy quality assurance as a tool for maneuvering power grid capacity. The energy market requires a clear adherence to electricity quality indicators, which increases the requirements for both the operation of the equipment and its control systems. An integration of fault detection and isolation methods into the automatic control circuits is very promising in this case. The failure of sensors, actuators, or unexpected behavior of the control object can be determined until the irreversible development of the emerging situation. This will increase the duration of trouble-free operation of the equipment, the quality of technological processes and reduce the cost of maintenance. The use of fault-tolerant control systems should be considered both at the design stage of new facilities and during the modernization and operation of existing power plants. The use of fault-tolerant systems for the automatic control of heat and power facilities and complexes in real time can help to measure profitability and then increase the amount of labor force through specialized asset analysis software to manage the profitability of real-time operations.

\section{References:}

1. Information on the operation of the power complex for the 12 months of 2018. URL: http://mpe.kmu.gov. ua/minugol/control/uk/ publish/article?art_id=24533782 7\&cat_id=245183225 (the date of request: 27.07.2019).

2. Khalatov A.A. Energy Sector of Ukraine: modern state and nearest prospects. Visn. Nac. Akad. Nauk Ukr. (№ 6), 2016. P. 53.

3. Jerome, R. Power Plant diagnostics go online. American Society of Mechanical Engineers. 111(12), 1989. P. 62.

4. Khalatov A.A., Karp I.N., Kutsan Yu.G. The power gas turbines: prospects of application in power engineering of Ukraine / Visn. Nac. Akad. Nauk Ukr. (№ 11), 2015. P. 52.

5. The Energy Strategy of Ukraine till 2035. URL: http://mpe.kmu.gov.ua/minugol/control/uk/publish/ article?art id $=245239564 \&$ cat $\mathrm{id}=245239555$ (the date of request: 27.07 .2019 ).

6. Girshfeld V.Y., Morozov G.N. Thermal power plants: studies. for technical schools. 2nd ed. Energoatomizdat. Moscow, 1986. P. 226.

7. Himanshukumar R. Patel, Dr. Vipul A. Shah. Fault detection and diagnosis methods in power generation plants - the Indian power generation sector perspective: an introductory review. PDPU Journal of Energy \& Management Vol.2, No.2. Pandit, 2018. P. 31-49.

8. Toffolo, A. Fuzzy. Expert Systems for the Diagnosis of Component and Sensor Faults in Complex Energy Systems. J. Energy Resour. Technol. 131 (4), 2009. P. 10.

9. Mostafa S., Lee S.H., Dumrak J., Chileshe N., Soltan H. Lean Thinking for a Maintenance Process. / Prod. Manuf. Res., 2015. P. 236-272.

10. Transfer of DTEK Prydniprovska TPP to the gas coil of Ukrainian mining. URL: https://www.youtube. $\mathrm{com} / \mathrm{watch}$ ? $\mathrm{v}=$ Xqy4-miIVVI (the date of request: 5.09.2019).

\section{СТеПанець О.В., Шрам Д.О. ЗАСТОСУВАННЯ ВІДМОВОСТІЙКИХ СИСТЕМ АВТОМАТИЧНОГО КЕРУВАННЯ НА ТЕПЛОВИХ ЕЛЕКТРОСТАНЦІЯХ}

Метою статті $\epsilon$ порівняння виробництва електроенергії на різних типах електростанцій, зокрема ознайомлення зі сферою сучасної теплоенрегетики України, формування загального огляду проблем автоматичних систем керування тепловими та енергетичними об' єктами та комплексами. 
Енергоринок вимагає чіткого дотримання показників якості електроенергії, на яку впливає стан основних виробничих активів електростанцій та якість керування ними. У сучасній світовій парадигмі розвитку теорії автоматичного керування перспективними виглядають відмовостійкі системи керування, спрямовані на забезпечення безаварійності технологічних прочесів.

У статті наводиться динаміка зміни співвідношення між окремими джерелами енергї̈ за останні роки, що вплине на напрямок досліджень через оцінку використання окремих джерел енергії у майбутньому. Існує низький рівень толерантності до зниження продуктивності в електростаниіях. У них є чимало проблем та можливих несправностей, таких як низька продуктивність, втрати виробництва, безпека людини, небезпека для навколишнього середовища та забруднення. Щоб уникнути небажаних умов та забезпечити безперебійну електроенергію промисловим та іншим споживачам, енергетична галузь почала використовувати методи виявлення та ізоляції несправностей на електростанціях. Розглянуто сучасний стан теплових електростанцій, які використовуються у маневрових режимах. Детально розглянута схема роботи теплової електростанції, визначені ключові елементи, які потребують контролю та застосування відмовостійких систем керування. Наведені основні аспекти відмов в контурах автоматичного керування. Відносно иих аспектів проаналізовано типову електростанцію та на прикладах показані причини та місия відмов у головних структурних елементах електростаниії-турбіні, котлоагрегаті, підсистемах горіння, водоподачі, пароутворення та паровикористання. Показано роль відмовостійких систем у стратегї обслуговування об'єкта керування, що реалізуються як на етапі проєктування, так і в процесі експлуатації.

Ключові слова: виробництво електроенергї̈, виявлення та ізолювання несправностей, діагностика несправностей, відмовостійка система, електростаниія, стратегія обслуговування. 